Vol. 1 No. 3 Juli 2021 e-ISSN : 2774-6283 | p-ISSN : 2775-0019

\title{
UPAYA PENINGKATAN MOTIVASI BELAJAR DENGAN MENGGUNAKAN MODEL PEMBELAJARAN KOOPERATIF PENDEKATAN MIND MAPING PADA MATA PELAJARAN MENGGAMBAR TEKNIK DASAR
}

\author{
SURYANI \\ SMKN 2 Bone Sulawesi Selatan \\ Email : suryanihisbul@g.mail.com
}

\begin{abstract}
ABSTRAK
Penelitian ini dilatar belakangi oleh fenomena bahwa mata pelajaran menggambar teknik dasar pada Kelas X Kompetensi keahlian Desain pemodelan dan Informasi bangunan SMK Negeri 2 Bone memiliki tingkat kesulitan yang cukup tinggi. Selain aspek psikomotorik, yang lebih menyulitkan adalah aspek kognitif pada mata pelajaran tersebut. Banyak siswa yang kesulitan memaknai materi pembelajaran dengan baik. Diduga salah satu penyebabnya adalah karena proses pembelajaran hanya berpusat pada guru, sehingga siswa tidak ikut terlibat secara aktif dalam proses belajar mengajar tersebut. Hal ini berdampak pada rendahnya interaksi antara guru dan siswa maupun antara siswa.. Penelitian ini bertujuan melakukan perbaikan proses pembelajaran dengan harapan jika proses membaik maka akan terjadi peningkatan prestasi belajar. Penelitian ini berjenis penelitian tindakan kelas, dilaksanakan di SMK Negeri 2 Bone, padal kelas X Kompetensi keahlian desain pemodelan dan informasi bangunan semester ganjil tahun pelajaran 2019/2020.Pada penelitian ini secara faktual terlihar bahwa penggunaan pendekatan model mind mapping terbukti efektif sebagai pendekatan model pembelajaran untuk membantu siswa dalam memahami konsep konsep dan mengkotekstualisasikan konsep konsep yang dipahami.Hal ini terlihat dari peningkatan berbagai aspek yang diobservasi sepanjang siklus1 hingga siklus 3 dalam penelitian tindakan kelas ini. Aspek kerja sama antar siswa meningkat sebesar $47,5 \%$, aspek interaksi dengan guru meningkat sebesar $60,6 \%$. Pada aspek tanggung jawab mengalami peningkatan $51,52 \%$, dan ikuti penigkatan pada aspek kehadiran sebesar 3.04\%. Sebagai konsekoensi logis dari membaiknya proses pembelajaran, rata rata prestasi belajar siswa juga mengalami peningkatan sebesar 29, $14 \%$.
\end{abstract}

Kata kunci : Mind Maping, perbaikan proses bealajar, aspek kognitif menggambar teknik

\section{PENDAHULUAN}

Peningkatan hasil belajar bukan hanya didukung oleh kemampuan dan kemauan, tetapi model pembelajaran yang digunakan oleh guru juga akan mempengaruhi hasil belajar siswa. Metode pembelajaran sebagai faktor eksternal dalam proses pembelajaran sangat menunjang keberhasilan proses belajarsiswa. Metode pembelajaran yang tepat, dapat memperbaiki proses pemebalajaran sehingga tercipta situasi belajar yang kondusif, motivatif dan ekploratif pada kemampuan belajar siswa. Metode pembelajaran harus kompatibel dengan materi pelajaran yang disampaikan, sarana yang tersedia, kondisi siswa serta kemapuan penguasaan kompetensi.

Menurut Sari (2018:1591) bahwa guru seharusnya menciptakan suatu pembelajaran bervariasi agar tidak berpacu hanya pada buku guru. Lebih lanjut Ananda (2018:21) menyatakan bahwa guru harus aktif mencari informasi perkembangan model, metode, dan media pembelajaran mutakhir dari berbagai sumber (Nurjanah, 2020).

Pemahaman konsep merupakan landasan yang harus dimiliki siswa untuk menyelesaikan persoalan-persoalan matematika maupun persoalan-persoalan dalam kehidupan sehari-hari. Dengan memahami konsep siswa akan lebih mudah mempelajari materi yang diterima. Selain itu siswa juga akan lebih mudah untuk menerima konsep baru. Memahami konsep bukan hanya dengan menghafal namun dengan mempelajari contoh-contoh konkret sehingga siswa mampu mendefinisikan sendiri suatu informasi.(Ernawati, 2019)

Pemahaman konsep yang baik harus dibangun sedini mungkin pada mata pelajaran menggamabar teknik dasar, karena hal tersebut akan memudahkan siswa dalam 
mengkotekstualisasikan konsep konsep gambar pada pelajaran selajutnya, misailnya pada mata pelajaran desain interior maupun autocad. Tanpa pemahaman konsep yang baik mata pelajaran gambar teknik dasar tidak akan memberikan daya yang cukup kepada siswa untuk mengembangkan kemampuannya pada mata pelajaran yang terhubung dengan materi gambar dasara teknik. Faktor inilah yang mengharuskan pada mata pelajaran gambar teknik dasar, siswa tidak hanya perlu kompeten pada aspek psikomotorik tapi juga pada aspek kognitif.

Belajar hakikatnya adalah kegiatan yang mengharapkan perubahan tingkah laku pada individu yang berproses. Kemampuan baru yang diperoleh serta perubahan perilaku yang diperoleh dari proses yang terjadi menunjukkan telah terjadi proses belajar. Menurut paiaget, adaptasi adalah proses penyesuain skema dalam merespon lingkungan melalui asimilasi dan akomodasi.(Piaget \& Piaget, 2010). Oleh karena itu diperlukan situasi yang memungkinkan siswa mampu melakukan asimilasi dan akodasi ilmu pengetahuan dengan mudah dan menarik.

Ada beberapa kemampuan yang diperlukan dalam proses mengkonstruksi pengetahuan, yaitu (1) Kemampuan mengingat dan mengungkapkan kembali pengalaman (2) Kemampuan membandingkan dan mengambil keputusan akan kesamaan dan perbedaan dan (3) kemampuan untuk lebih menyukai suatu pengalaman yang satu dari pada lainnya (Budiningsih, 2005). Kemampuan untuk menyukai suatu pengalaman terkait erat dengan motivasi seseorang. Dari perspektif motivasional pada pembelajaran kooperatif, salah satu hal yang dapat mendorong terciptanya motivasi adalah kerjasama dalam kelompok. (Slavin, 2008). Kelompok harus memiliki tujuan bersama, dan individu tidak memiliki cara lain untuk sukses selain menyuseskan kelompoknya. Dengan pencipataan suasana seperti tersebut diatas, terbentuk rasa saling bergantung antar pribadi dalam kelompok tersebut.

Metode mind mapping atau peta pikiran adalah suatu metode untuk memaksimalkan potensi pikiran manausia dengan menggunakan otak kanan dan otak kirinya secara simultan(Sulfemi, 2019). Pembelajaran dengan metode Mind Mapping adalah pembelajaran yang didesain agar siswa memiliki keterampilan belajar kreatif yang dapat membantu siswa untuk menghubungkan suatu konsep-dengaan konsep lainya, sehingga siswa dapat memahami konsep dengan baik. Mind mapping merupakan salah satu tipe dari pembelajaran kooperatif. Mind Mapping diperkenalkan oleh Buzan tahun 1990 dan merupakan metode pembelajaran yang mengharuskan peserta didik untuk mengungkapkan inti dari materi pembelajaran. Tapantoko (2011:33) menjelaskan bahwa metode mind mapping lebih menekankan pada keaktifan dan kegiatan kreatif siswa, sehingga akan meningkatkan daya hafal dan pemahaman konsep siswa yang kuat.(Faelasofi, 2016)

Mind mapping menggunakan keterampilan-keterampilan yang dapat menggabungkan berbagai informasi sehingga dapat menyampaikan dan menerima informasi dengan mudah. Mind mapping menggunakan pengingat visual dan sensorik dalam suatu pola dari ide yang saling berkaitan. Hal ini sejalan dengan pendapat Shoimin (2014: 105), mind mapping merupakan cara kreatif bagi tiap siswa untuk menghasilkan gagasan, mencatat apa yang dipelajari, atau merencanakan berbagai tugas baru (Nurjanah, 2020).

Berdasarkan hal tersebut maka penulis mengambil sebuah inisiatif pendekatan mind maping pada mata pelajaran menggambar teknik dasar. Dengan menerapkan hal tersebut diharapkan terjadi peningkatan kualitas proses belajar serta peningkatan prestasi belajar pada siswa Kelas X DPIB SMKN 2 Bone Tahun Pelajaran 2019/20.

\section{METODE PENELITIAN}

Penelitian ini merupakan Penelitian Tindakan Kelas (classroom action research), karena penelitian dilakukan untuk memecahkan masalah pembelajaran di kelas. Penelitian ini juga termasuk penelitian diskriptif, sebab menggambarkan bagaimana pembelajaran active learning diterapkan dan bagaimana hasil dari penerapan pendekatan mind maping tersebut.

Dalam penelitian ini, guru sebagai peneliti, di mana guru berperan sebagai seorang perencana, pelaksana, dan reflektor. Untuk pelaksanaan observasi dibantu oleh guru sejawat dalam kegiatan pembelajaran mengagambar teknik dasar dengan pendekatan mind maping. 
1. Tempat, Waktu dan Subyek Penelitian

Tempat penelitian adaalah SMK Negeri 2 Bone. Penelitian mengambil kelas $\mathrm{X}$ Kompetensi keahlian desain pemodelan dan informasi bangunan. Dilaksanakan pada semester ganjil tahun pelajaran 2019/2020.

2. Rancangan Penelitian

Penerapan pembelajaran dengan pendekatan mind maping menggunakan model penelitian tindakan dari Kemmis dan Taggart,(Arikunto, 2013), yaitu berbentuk spiral dari siklus yang satu ke siklus yang berikutnya. Setiap siklus meliputi planning (rencana), action (tindakan), observasi (pengamatan) dan reflection (refleksi). Langkah pada siklus berikutnya adalah perencanaan yang sudah direvisi, tindakan, pengamatan dan refleksi.

3. Subyek penelitian

Siswa kelas X DPIB semester Ganjil Tahun Pe;ajaran 2019/2020

4. Sumber data

- Data awal berupa nilai post test

- Data siklus 1 hingga siklus 3 berupa data tentang motivasi belajar dan nilai hasil pelajaran gambar.

5. Teknik Pengumpulan data

- Adapun teknik pengumpulan data yang digunakan dalam penelitian ini yaitu tes dan non tes. Tes untuk mengukur prestasi belajar menggunakan kriteria hasil belajar dan metode non tes untuk penilaian motivasi belajar siswa.

6. Validitas data

- Menggunakan Triangulasi data yaitu dengan kolaborasi dalam pembuatan lembar observasi anatara peneliti dengan rekan sejawat, guru SMK N 2 Bone.

\section{HASIL DAN PEMBAHASAN}

\section{A. Hasil}

Penelitian ini terdiri dari 3 siklus, dengan 4 Aspek amatan dimensi motivasi belajar serta nilai hasil belajar siswa. Hasil observasi dari keempat aspek tersebut diharapkan mewakili dimensi motivasi belajar pada siswa atau memberikan gambaran tingkat dorongan siswa dalam mengikuti proses belajar. Berdasarkan hasil observasi dimensi motivasi siswa diperoleh data sebagai berikut ;

Tabel 1. Peningkatan Motivasi Belajar

\begin{tabular}{|c|c|c|c|c|c|}
\hline No & Aspek yang dinilai & $\begin{array}{c}\text { Kondisi } \\
\text { Awal } \\
(\%)\end{array}$ & $\begin{array}{c}\text { Siklus1 } \\
(\%)\end{array}$ & $\begin{array}{c}\text { Siklus } 2 \\
(\%)\end{array}$ & $\begin{array}{c}\text { Siklus } 3 \\
(\%)\end{array}$ \\
\hline 1 & $\begin{array}{c}\text { Kerjasama dalam } \\
\text { Kelompok }\end{array}$ & 0 & 40 & 62 & 87.5 \\
\hline 2 & $\begin{array}{c}\text { Interaksi siswa dengan } \\
\text { guru }\end{array}$ & 21.21 & 30.33 & 75.75 & 90.90 \\
\hline 3 & $\begin{array}{c}\text { Tanggung jawab dalam } \\
\text { proses belajar }\end{array}$ & 15.15 & 48.48 & 75.75 & 100 \\
\hline 4 & Kehadiran siswa & 90.90 & 96.96 & 100 & 100 \\
\hline
\end{tabular}

Untuk hasil prestasi belajar, ada 5 variabel yang di tinjau pada prestasi belajar. Pada table 2 dan table 3 terlihat sejauh mana pendekatan mind mapping mampu membantu proses belajar baik secara individual maupu klasikal. dan tabel akan diperoleh gambaran hasil belajar. Nilai terendah dan tertinggi menunjukkan hasil belajar secara individual sedangkan rerata dan rentang nilai memperlihatkan prestasi secara klasikal. 
Vol. 1 No. 3 Juli 2021 e-ISSN : 2774-6283 | p-ISSN : 2775-0019

Tabel 2 . Nilai Hasil Prestasi Belajar

\begin{tabular}{|c|c|c|c|c|c|}
\hline No & Uraian & $\begin{array}{c}\text { Nilai Tes } \\
\text { Awal }\end{array}$ & $\begin{array}{c}\text { Nilai Tes } \\
\text { Siklus1 }\end{array}$ & $\begin{array}{c}\text { Nilai Tes } \\
\text { Siklus } 2\end{array}$ & $\begin{array}{l}\text { Nilai Tes } \\
\text { Siklus } 3\end{array}$ \\
\hline 1 & $\begin{array}{c}\text { Nilai } \\
\text { terendah }\end{array}$ & 46 & 51 & 65 & 67 \\
\hline 2 & $\begin{array}{l}\text { Nilai } \\
\text { tertinggi }\end{array}$ & 83 & 88 & 89 & 91 \\
\hline 3 & Nilai rerata & 60.63 & 71.54 & 75.87 & 78.30 \\
\hline 4 & Rentang Nilai & 37 & 37 & 24 & 27 \\
\hline
\end{tabular}

Interval peningkatan hasil belajar sebagai mana yang ditampilakn pada table 3 membantu kita untuk melakukan kategorisasi siswa untuk keperluan perbaikan proses dan evaluasi formatif. Kemampuan prestasi belajar juga dapat dibaca pada data interval peningkatan presetasi belajar, data ini memudahkan untuk melakukan pengelompokan siswa betrdasarkan kemampuan ataupun pengelompokan untuk keperluan tutor sejawat.

Tabel 3. Interval Peningkatan Prestasi belajar

\begin{tabular}{cccccc}
\hline No & Interval & $\begin{array}{c}\text { Frekuensi } \\
\text { Kondisi } \\
\text { awal }\end{array}$ & $\begin{array}{c}\text { Frekuensi } \\
\text { Siklus 1 }\end{array}$ & $\begin{array}{c}\text { Frekuensi } \\
\text { Siklus 2 }\end{array}$ & $\begin{array}{c}\text { Frekuensi } \\
\text { Siklus 3 }\end{array}$ \\
\hline 1 & $45-49$ & 3 & 0 & 0 & 0 \\
\hline 2 & $50-54$ & 9 & 1 & 0 & 0 \\
3 & $55-59$ & 6 & 2 & 0 & 0 \\
\hline 4 & $60-64$ & 5 & 2 & 0 & 0 \\
5 & $65-70$ & 3 & 2 & 1 & 3 \\
6 & $71-74$ & 3 & 19 & 16 & 0 \\
\hline 7 & $75-79$ & 2 & 3 & 8 & 16 \\
\hline 8 & $80-84$ & 2 & 2 & 5 & 8 \\
\hline 9 & $85-90$ & 0 & 2 & 3 & 5 \\
\hline 10 & $91-94$ & 0 & 0 & 0 & 1 \\
\hline 11 & $95-100$ & 0 & 0 & 0 & 0 \\
\hline & & & & & \\
\hline
\end{tabular}

\section{B. Pembahasan}

Motivasi belajar siswa tercermin dari 8 indikator, yaitu durasi kegiatan,frekuensi kegiatan, presistensi, devosi dan pengorbanan, ketabahan,keuletan dan kemampuan, tingkat inspirasi, tingkatan kualifikasi hasil, dan arah sikap terhadap sasaran kegiatan.(Andriani \& Rasto, 2019). Indikator indicator tersebut terakumulai pada empat aspek yang diobeservasi. Hasil observasi dari siklus 1 ke siklus akhir terjadi peningkatan motivasi belajar siswa berdasarkan observasi yang dilakukan oleh kolaborator dari kondisi awal ke kondisi akhir menunjukkan terjadi peningkatan dari semua aspek yaitu yaitu aspek kerjasama dalam kelompok terjadi peningkatan sebesar $47,5 \%$.

Pada aspek interaksi dengan guru terjadi peningkatan sebesar 60,6\%. Pada aspek tanggungjawab terjadi peningkatan 51,52\%. Pada aspek kehadiran terjadi peningkatan sebesar $3,04 \%$. Pembelajaran dengan menggunakan pendekatan mind mapping menghasilkan peningkatan prestasi belajar dari siklus 1 ke siklus 3 sebesar 29,4\% dan nilai terendah dari kondisi awal ke kondisi akhir terjadi peningkatan sebesar $445,65 \%$ serta pada nilai tertinggi terjadi peningkatan $6,02 \%$.

Merujuk pada Taksonomi Bloom hasil belajar dalam rangka studi dicapai melalui tiga ranah, yaitu kognitif, afektif, psikomotor (Sudjana, 2009). Ranah kognitif, berkaitan dengan hasil belajar intelektual yang terdiriatas 6 aspek yaitu pengetahuan, pemahaman,penerapan, analisis, sintesis, dan penilaian.ranah afektif, berkaitan dengan sikap dan nilai ranah afektif meliputi lima jenjang kemampuan yaitu menerima, menjawab, atau 
reaksi,menilai, organisasi dan karakterisasi dengan suatu nilai atau kompleks. Nilai ranah psikomotor meliputi keterampilan motorik, manipulasi benda-benda, koordinasi neuromuscular (menghubungkan, mengamati) (Andriani \& Rasto, 2019).

Pemahaman konsep merupakan suatu aspek yang sangat penting dalam pembelajaran, karena dengan memahami konsep siswa dapat mengembangkan kemampuannya dalam setiap materi pelajaran.(Faradila, 2019). Pada pembelajaran dengan menggunakan pendekatan mind maping membuat siswa tertarik dalam memahami konsep menggambar teknik, karena Mind mapping menggunakan pengingat visual dan sensorik dalam suatu pola dari ide yang saling berkaitan(Nurjanah, 2020). Dengan pendekatan ini siswa antusias dengan proses pemebelajaran dan pada akhirnya pada umumnya siswa dapat merumuskan konsep konsep yang diberikan oleh guru..

Pada awalnya terdapat keengganan siswa belajar dalam berkelompok dan melakukan interaksi yang intensif sesama kelompok. Juga terasa sulit membangun interaksi antara siswa dengan guru. Seiring berlangsungnya pembelajaran dengan pendekatan mind mapping dengan menggunakan bantuan peraga kartu bertuliskan konsep konsep gambar. Pengkodisian siswa untuk belajar bersama dalam kelompok terus didorong dalam setiap siklusnya, niscaya akan terbangun pola belajar kolaboratif. Mengingat bahwa kelompok sebaya merupakan lingkungan pergaulan seseorang di mana anggota-anggotanya memiliki kesamaan karakteristik dari segi usia, latar belakan sosial atau perkembangan kepribadian. Kelompok sebaya menjadi tempat bagi para anggotanya untuk bersosialisasi (Pranyoto \& Belang, 2019).

Ketertarikan siswa semakin berkembang dan kerja sama antar siswa dalam kelompok semakin tumbuh. Hal ini disebabkan karena terdapat saling ketergantungan antar siswa dalam menyusun puzle konsep yang harus saling dihubungkan antara peraga kartu yang di sebar disetiap anggota kelompok. Juga terdapat semangat untuk mengembagkan kemampuan kelompok karena ada kompetisi yang positif antar kelompok.

Di siklus ketiga ada penurunan rentang nilai hasil belajar. Ini disebabakan oleh adanya siswa yang mengalami penurunan hasil belajar disiklus dan ada yang melesat sendiri menembus kategori nilai 90-91. Sementara kategori menengah lebih dominan.

\section{KESIMPULAN}

Dari hasil penelitian dapat disimpulkan sebagai berikut :

1. Pembelajaran dengan mengunakan pendekatan mindmapping pada mata pelajaran mengambar teknik dasar di kelas X semester ganjil 2019/2020 SMK Negeri 2 Bone efektif dalam meningkatkan motivasi belajar.

2. Pembelajaran dengan mengunakan pendekatan mindmapping pada mata pelajaran mengambar teknik dasar di kelas X semester ganjil 2019/2020 SMK Negeri 2 Bone dapat meningkatkan prestasi belajar siswa, baik secara individual maupun secara klasikal.

\section{DAFTAR PUSTAKA}

Andriani, R., \& Rasto, R. (2019). Motivasi belajar sebagai determinan hasil belajar siswa. Jurnal Pendidikan Manajemen Perkantoran .... https://ejournal.upi.edu/index.php/jpmanper/article/view/14958

Arikunto, S. (2013). Prosedur penelitian suatu pendekatan praktik. hellis.litbang.kemkes.go.id. http://hellis.litbang.kemkes.go.id:8080/handle/123456789/62880

Budiningsih, A. (2005). Belajar dan pembelajaran. In Jakarta: Rineka Cipta.

Ernawati, E. (2019). PENGARUH MODEL PEMBELAJARAN KOOPERATIF TIPE MIND MAPPING TERHADAP KEMAMPUANPEMAHAMAN KONSEP MATEMATIS SISWA KELAS VIII.

Faelasofi, R. (2016). Penerapan Metode Mind Mapping Pada Pembelajaran Matematika. In JURNAL e-DuMath. ejournal.umpri.ac.id. https://ejournal.umpri.ac.id/index.php/edumath/article/download/181/124 
Faradila, D. (2019). Memahami konsep. http://repository.unim.ac.id/38/3/BAB II .pdf

Nurjanah. (2020). ANALISIS PENGARUH MODEL PEMBELAJARAN KOOPERATIF TIPE MIND MAPPING TERHADAP HASIL BELAJAR SISWA SD. JURIDIKDAS: Jurnal Riset .... https://ejournal.unib.ac.id/index.php/juridikdasunib/article/view/14502

Piaget, J., \& Piaget, J. (2010). El constructivismo. Revista Nova Escola-Edição. https://intensivopedagogico.com.br/wp-content/uploads/2016/12/Concepções-daAprendizagem-2.pdf

Pranyoto, Y. H., \& Belang, B. (2019). Pengaruh Fasilitas Belajar, Kelompok Sebaya dan Profesionalisme dosen terhadap hasil belajar mahasiswa di sekolah tinggi katolik santo yakobus merauke. Jurnal Masalah Pastoral. https://ojs.stkyakobus.ac.id/index.php/JUMPA/article/view/71

Slavin, R. E. (2008). cooperative lerning. Erlangga.

Sudjana, N. (2009). Dasar-dasar Proses Pembelajaran. Sinar Baru Algesindo.

Sulfemi, W. B. (2019). Model pembelajaran kooperatif mind mapping berbantu audio visual dalam meningkatkan minat, motivasi dan hasil belajar IPS. Jurnal PIPSI (Jurnal Pendidikan IPS ....

https://journal.stkipsingkawang.ac.id/index.php/JurnalPIPSI/article/view/1204 